\title{
Processing Use and Analysis of Inventory (stock-taking) of the Essences Exploited in the United Forestry Exploitation of Gouongo in the Republic of Congo
}

\author{
Pierre MBETE ${ }^{1,2 *}$ \\ ${ }^{1}$ National University of Agronomy and Forestry of Marien Ngouabi University BP 69 \\ ${ }^{2}$ Applied Ecological Laborratory and Environmental, Brazzaville, Congo \\ *Corresponding author
}

\begin{tabular}{|l|}
\hline Ke y w o r d s \\
Inventory, \\
$\begin{array}{l}\text { Essences, Diameter, } \\
\text { cubage, Stem }\end{array}$ \\
\hline Article Info \\
\hline $\begin{array}{l}\text { Accepted: } \\
\text { 30 May } 2020 \\
\text { Available Online: } \\
\text { 10 June } 2020\end{array}$ \\
\hline
\end{tabular}

\section{Introduction}

After the Amazon's basin, the forests of Congo basin constitute the world's second tropical massive. It is a wide compact soil about 300 millions hectares (FAO, 2011)
In the Republic of Congo the planning strategies of devolpment and preservation of natural ressources are two main important factors for the national economic growth. In all forested areas, the Congolese government oblige all forestry entreprises to put in place arrangement plans and to have a strong relationship between them in order to show up the importance of our forest with a concerted management ecologically controlled, socially and economically viable. Commercial value of forestry essences estimation was made to plan the processes of viable and right forestry exploitation in the Nianga area especially in the block number B. Many strategies were put in place in order to treat the sizes of land in order to know the sizes of land. We noticed forestry pistes in the block Bwith a realisation forestry piste of 99,55 . Wide, rate and its rate estimation is about $0,90 \%$. The relative dominance of stem density exploited and marketable shows that, Okoumé (Aucoumea klaineana) is predominate with $30,59 \%$ and has a cubage of $1,927 \mathrm{~m}^{3} /$ ha after comes Essia (Perteranthus macrocarpus) with a relative dominance of $25,81 \%$ and an avaraye cubage of $\left(1,196 \mathrm{~m}^{3} / \mathrm{ha}\right)$ and finally comes Ebiara (Berlinia bracteosa) with $23,8 \%$ and on avarage cubage of $\left(0,73 \mathrm{~m}^{3} / \mathrm{ha}\right)$. Others essences are less represented, some are not represented at all in general 10 groupes of essences have been constituted according to its diameter imposed by the administration in charge of forests. The works on precessing analysis of forestry inventories of united forestry of Gouongo precisely in the block B shows that ecological system presents anenormous forester biological diversity. The administration of forest should have to put in place a good management strategy mostly on renewal essences, and to seed new plants in order to preserve some essences like Okoumé. 
complicated because of the strong cloudy coverage, fragmentation and diversity of the land- scape. Whereas the land inventorie are limited by a very large space and inaccessibility of the concerned land (OSFAC, 2010). The remark is that, the biodiversity on the level of the landscapes of forests of that massive is exptionnally expressed, which made the use and management of forestry ressources and faunal of differents biotopes are actually a political, économical and social matter for the governmental organizations, and searchers (FAO, 2011).

The Congolese forest is nearly large 22,5 millios hectares and represents more than $12 \%$ of forests of middle Africa and more than $10 \%$ of those of Congo basin, and has an ecological and socio-économical role. Heterogène naturally, the Congolese forest is caracterised by a biological wealth and a diversity of amazing landscape. In order toallow the preservation and management of the territory, several protected areas have been gradually created, covering the surface of 3655,402 ha, that is to say $11 \%$ of the national surface (UICN, 2012).

The Congolese forests are classified as following:

Le nord Congo (north Congo) which covered about 15 millions hectares;

Le Chaillu which covered about 3,5millions hectares;

Le Kouilou-Mayombe covered about 1,4 millions hectares (Vennetier, 1977).

The forestry exploitation which the incidence application has differents wood's extraction operations shows that, this exploitation caused many damages and has several consequences on the renewal of the most exploited essences.
According to (Mbete \& al., 2018), the most wanted essences needed in the market which are commercial are highly exploited, and serveral damages happened to the young stems, while those stems are considered as the future essences in the forester sites then the question is to know, how many of those most exploited young stems are still in the forest and what will happen in being highly exploited?

(Mbete and al., 2015) explain that for a very longtime, African's dense forests were considered as «poors » in terms of labour's wood commercial species. Previously studies showed that the overage numeration of each forestery exploitation was $8 \mathrm{~m}^{3} /$ ha versus $13 \mathrm{~m}^{3} /$ ha of American forests and $27 \mathrm{~m}^{3} /$ ha of Asian forest.

In whole African, particulary in Congoforests, it was important to run through big areas in order to get a regular and enough supplying labour woods in order to satify the need of industries that transform woods (Mbete and al., 2015).

Actually the multiplication of different species in the middle African's rain forests there is a regular numeration in cubage. This new system can have or not beneficial,incident on the regeneration of new essences (Mbete et al., 2015) show that the analysis of inventory allowed and show the difference between the differents steps of developpement while the stems which is kept for the coming decreasing move can lead to damages in the future.

Acording to these authors, the application of inventory showed that among the most exploited essences by the forestery compagnies were highly occupied whereas damages were previouly known as more important, those inventories are made for a rational and durable planning in order to 
compare and manage more judiciary the step of developpement of the most wonted essences.

In the north forestry area of the country several forestry conferences have been organised the departement in charge of forest organizations (arrangement) in the whole forestries areas of the southern and central part of the country (Mbete and Oko., 2018) showed a particular interest to manage rationally forestry ressources of that area which the exploitation existed since the colonial periode it is in this context that the importance of forestry ofGouongowhich aims at: analysingand processing treatment of forestry inventeries of that area. The only goal is based on the following.

Analysis of tree sizes in the practice area and based on the followings:

Quote all exploited essences by the congolese wods industries of Niari;

Determine the number of stems by diameter rank in the blockB;

Determine the effectives per hectare in the block B;

Calculate the middle cubage in hectare per the block B;

Determine the relative dominance of the element in the block.

\section{Materials and Methods}

Material for the floristic inventory of data collection;

Material of cartographie (Raster data);

Technical material.

The implementation of forestry inventory involves first a work which goes from the preparation of a survey plan during the edition of the ground transcripts and the printives of the final thematic cards so during our work, the material below has been used: a) (01) laptop toshiba Satellite c855 (Rentium ® B970);

b) (01) Square;

c) One (01) GPS Garmin Map60CX;

d) One (01) software DNR Garmin;

e) One (01) software ArcGis Map10.0;

f) One (01) satellite picture landSat 7ETM(24 April 2002 and 10 April 2006);

g) Topographic founds Kibangou (rectified pseudo ortho) and Mossendjo (rectified pseudo ortho);

h) New shapefiles for the study area;

i) Pencils and pens;

j) Paper size A4 and A3;

k) Layonnage and counting cards.

\section{Method of the development of cards}

The method of the office had consisted to the cartography works in:

Updating existant entities (shapefils);

Aeating new entities of the physical milieu of the study area;

Updating attributes;

Developping and publishing thematic cards.

\section{Treatment method of dendrometric data}

The compilation of transcripts card had consisted inlayoningand counting. The compilation process is there fore to count the received cards, codify and control some details such as:

The inventory block number where in our case it is the block B;

Layons and sample unities number;

Essences you should give: the code, diameter class, quality, azimut, slope, shopes correction, theoretical and realzed length;

Existant space between total length of layon and sample unities number.

The dendrometric data treatment has consisted in intregreting those data in a 
planning unit programme (Moukilou, 2012) in which:

Parameter $(\mathrm{Xi})=\Sigma(\mathrm{X} 1+\mathrm{X} 2+\mathrm{X} 3+\ldots+\mathrm{Xn})$ where $\mathrm{Xi}$ represents the population (example, the population of Okoumé);

Average $(\mathrm{Xi})=\Sigma(\mathrm{Xi}) /(\mathrm{N}-1)$, where $\mathrm{N}$ represents the population size;

Variance $\left(\sigma^{2} \mathrm{xi}\right)=\Sigma(\mathrm{Xi}-\mathrm{Xi})^{2} /(\mathrm{N}-1)$;

Space-type $(\mathrm{Xi})=\mathrm{V}\left(\sigma^{2} \mathrm{xi}\right)$;

Variation coefficient $(\mathrm{Cv})=[$ Spacetype/Average (Xi)] x 100;

Standard Error $=$ Space-type $/ \mathrm{V}(\mathrm{N}-1)$;

Sample Error $=$ Standard Error Xt, where $\mathrm{t}$ represents the probability rate read in the Student table, which varies according to the probability threshold and the number of freedom degree. Confidence degree retained in the course of our works is $95 \%$, given 1,96(value read in the Student table);

Precision $=$ Average \pm Sample error .

Data capture under the software LSCDIA have previously been brought back to ACCESS, then integreted in the programme, also in by an algorithmic liaison between this database and the cubage price previously developped by the CNIAF/PAGEF (2012). It has automatically generated dendrometric results-Company researched in particular: total numbers, terrier areas; medium numbers affected by the sample error; total crude volume; medium volumes affected by sample error.

At last, cubage price developped by the CNIAF/PAGEF has allowed to obtain parameters linked to the calcul of volumes.

\section{Results and Discussion}

\section{Survey plan}

The forecart survey plan has allowed us to make different operation to get finally a real survey rate. Based on the collected data and the digitalization of the areas opened, we have to calculate real survey rate. This one is presented in board 1. Inentory data (layonnage and counting) in cartographic database and the software use ArcGis 10.0 has allowed to produce a thematic eard (Face 1)

The analysis of the result of dendrometric inventory shows the representativity of made and exploited essences by the company in block B(face 2). The most preferable essences are the Essia (2251 stalks, followed by the Okoumé (1837 stalks) and the Ebiara (921 rods). The rest of stalks are slightly represented

Medium numbers of affected essences by the sample error accordingto their diameter class are presented in (figure 3). We see in this board 14 classes of diameter where intervals comprise between bounds of] $0-5[\mathrm{~cm}$ by the class of diameter. The class of the diameter 2 represents the dominant class where stalks are comprised between $] 5-10[\mathrm{~cm}$ followed by class 3 between stalks having a diameter comprises between] $10-15$ [ $\mathrm{cm}$ then classes 4 and 5.

As far as 6 and 8 classes are concerned, they are less represented and they are trees which have a diameter of exploitability often accepted by the forestery administration. From class 12 to 14 , those trees can be considered as seeds for the future rotations (Face 3).

The histogramme of face 4 emerged from invetories estimated in block Bshows that the repartition of medium volumes, the data treatment indicates that the volume of Okoumé essence is widely bigger with (5, $311 \mathrm{~m}^{3} / \mathrm{ha}$ ),followed by Essia essence with $\left(3,935 \mathrm{~m}^{3} / \mathrm{ha}\right)$ then the Ebiara which has $(2$, $096 \mathrm{~m}^{3} / \mathrm{ha}$ ). Those three essences are the most 
representative in block $\mathrm{B}$, just to them we have a percentage $68,86 \%$ for the set of essences exploited by company, the rest of essences are justyvery slightly represented, given $(31,14 \%$; The terrior area calculated in according to the biggest trees in hectare (possible tree for exploitation) here the diameter is comprised between $10-14 \mathrm{~cm}$ in our case, tree in which the diameter in $\mathrm{cm}$ varies between ]45-70.

Dendrometric results of the terrior area have shown that in all cares, trees in which the diameter varies between 10-12 occupy a great terrior area in $\mathrm{m}^{2} / \mathrm{ha}$, followed by trees which have the diameter comprises between 13-14, beyond $14 \mathrm{~cm}$, me have trees of very great diameter we cam consider as semence tree. However we see that essences as the Okoumé, Ebiara present the most considerable terrior areas. The results of terrior area $\left(\mathrm{m}^{2} / \mathrm{ha}\right)$ are mentionned in face 5 .

The calcul of the dominance relating to block Bis done by family gathering according to (Doucet, 2003) as well as the dominance relating to tal size of sample is presented in board 2 .

The set of diametric structure has revealed that the terrior area occupied by different families is $2,4 \mathrm{~m}^{2} /$ ha. We see that Burseraceae family has a percentage $(30,59 \%)$ with as essence the Okoumé is predominant, followed by Lecythidaceae with $(25,81 \%)$ where the essence Essia is the most predominant then the family of Fabaceae-caesalpinoideae with (23,08\%) comprising essences as: (Doussié, Ebiara, Movingui, Pao-rosa and Tali). Other family are very slighthy represented. It is about Meliaceae with essence as (Bossé, Dibetou, Kossipo, Sapelli, Sipo and Tiama); Fabaceae-papilionoideae (Padouk); Fabaceaeminosoideae (Okan); Rubiacceae (Bilinga); Moraceae (Iroko); Sapotaceae (Congotali, Douka, Longhi, Mouabi), and Ochnaceae (Izombé).

Dendrometric results of forestry inventory of block Bof the Exploitation Forestery Unity Gouongo have shown at the level of medium numbers possible for the forestery exploitation. In fact, statistic data present an incertainty margin as well as the number of each of essences.

The dominance relating to essences having a diameter superior or equal to the maximum diameter of official diameter. It is about Okoumé $(0,25 \mathrm{stalks} / \mathrm{ha})$ with a coefficient of variation 222, 40\%, followed by the Essia with $(0,22$ stalks/ha $)$ for a variation coefficient $234,87 \%$.

Board.1 Real survey rate

\begin{tabular}{|l|c|c|c|}
\hline \multicolumn{1}{|c|}{ Word } & Block A & Block B & Total \\
\hline Total area & 32041,97 ha & 50328,93 ha & $\mathbf{8 2 3 7 0 , 9 ~ h a ~}$ \\
\hline $\begin{array}{l}\text { Total length of counting layons really } \\
\text { opened }\end{array}$ & $129101 \mathrm{~m}$ & $179924 \mathrm{~m}$ & $\mathbf{3 0 9 0 2 5} \mathbf{~ m}$ \\
\hline Number of inventoried placettes & 647 & 900 & $\mathbf{1 5 4 7}$ \\
\hline Area really sounded out & 323,5 ha & $450 \mathrm{ha}$ & $\mathbf{7 7 3 , 5}$ ha \\
\hline Real survey rate & $\mathbf{1 , 0 1 \%}$ & $\mathbf{0 , 9 0} \%$ & $\mathbf{1 , 9 9 \%}$ \\
\hline
\end{tabular}


Board.2 Repartition of the essences exploited by the society with commercial names and scientific names of UFEGouongo

\begin{tabular}{|c|c|c|}
\hline S.No & Pilot Names & Scientific Names \\
\hline 1 & Acajou & Khaya anthotheca \\
\hline 2 & Bilinga 1 & Nauclea diderrichii \\
\hline 3 & Bilinga 2 & Nauclea diderrichii \\
\hline 4 & Bossé clair & Guarea cedrata \\
\hline 5 & Bossé foncé & Guarea thompsonii \\
\hline 6 & Congotali & Letestua durissima \\
\hline 7 & Dibetou & Lovoa trichiloides \\
\hline 8 & Douka & Tieghemella africana \\
\hline 9 & Doussié b. & Afzelia bipindensis \\
\hline 10 & Doussié P. & Afzelia pachiloba \\
\hline 11 & Ebiara & Berlinia bracteosa \\
\hline 12 & Essia & $\begin{array}{l}\text { Petersianthus } \\
\text { macrocarpus }\end{array}$ \\
\hline 13 & Iroko & Milicia excelsa \\
\hline 14 & Izombé & Testulea gabonensis \\
\hline 15 & Kossipo & $\begin{array}{l}\text { Entandrophragma } \\
\text { candollei }\end{array}$ \\
\hline 16 & Longhi blanc & $\begin{array}{l}\text { Chrysophyllum } \\
\text { africanum }\end{array}$ \\
\hline 17 & Moabi & Baillonella toxisperma \\
\hline 18 & Movingui & $\begin{array}{l}\text { Distemonanthus } \\
\text { benthamianus }\end{array}$ \\
\hline 19 & Okan & $\begin{array}{l}\text { Cylicodiscus } \\
\text { gabunensis }\end{array}$ \\
\hline 20 & Okoumé & Aucoumea klaineana \\
\hline 21 & Padouk blanc & Pterocarpus soyauxii \\
\hline 22 & Padouk rouge & Pterocarpus soyauxii \\
\hline 23 & Pao-rose & Bobgunia fistuloides \\
\hline 24 & Sapelli & $\begin{array}{l}\text { Antandrophragma } \\
\text { cylindicum }\end{array}$ \\
\hline 25 & Sipo & Entandrophragma utile \\
\hline 26 & Tali & $\begin{array}{l}\text { Erythrophleum } \\
\text { ivorense }\end{array}$ \\
\hline 27 & Tiama & $\begin{array}{l}\text { Entandrophragma } \\
\text { angolense }\end{array}$ \\
\hline
\end{tabular}


Board.3 Dominance relating to essences exploited by the company in block B

\begin{tabular}{|l|l|c|}
\hline Familles & Noms vernaculaires ou pilotes & Représentativité (\%) \\
\hline Burseraceae & Okoumé & 30,59 \\
\hline Fabaceae-Caesalpinioideae & Doussié bip, Ebiara, Movingui, Pao rose, Tali & 23,08 \\
\hline Fabaceae-Papilionoideae & Padouk blanc & 4,76 \\
\hline Fabaceae-Mimosoideae & Okan & 3,75 \\
\hline Lecythidaceae & Essia & 25,81 \\
\hline Meliaceae & $\begin{array}{l}\text { Acajou, Bossé foncé, Dibétou, Kosipo, } \\
\text { Sapelli, Sipo, Tiama }\end{array}$ & 5,90 \\
\hline Moraceae & Iroko & 1,80 \\
\hline Ochnaceae & Izombé & 0,85 \\
\hline Rubiaceae & Bilinga & 2,53 \\
\hline Sapotaceae & Douka & 0,92 \\
\hline TOTAL & & $\mathbf{1 0 0}$ \\
\hline
\end{tabular}

Face.1 Card of cutoff of the blocks of the Gouongo UFE of the A blocks and B in the south Congo, Survey plan of inventory blocks of planning unit of Company.

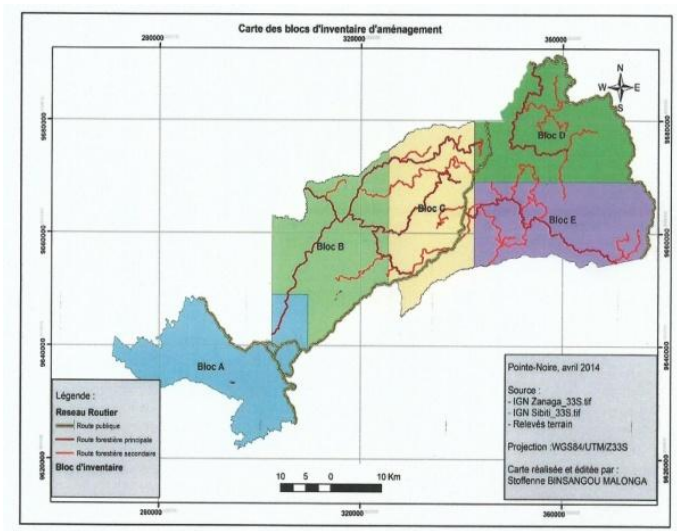

Face.2 Total numbers of stalks seen and exploited by the Company in block B

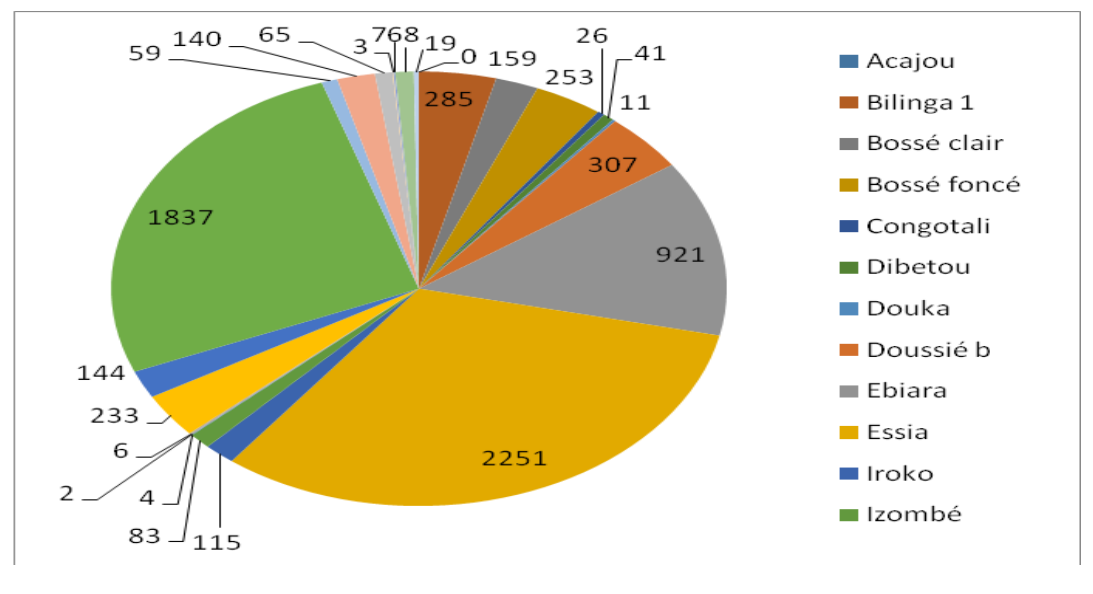


Face.3 Repartition of medium numbers according to the diameter classes

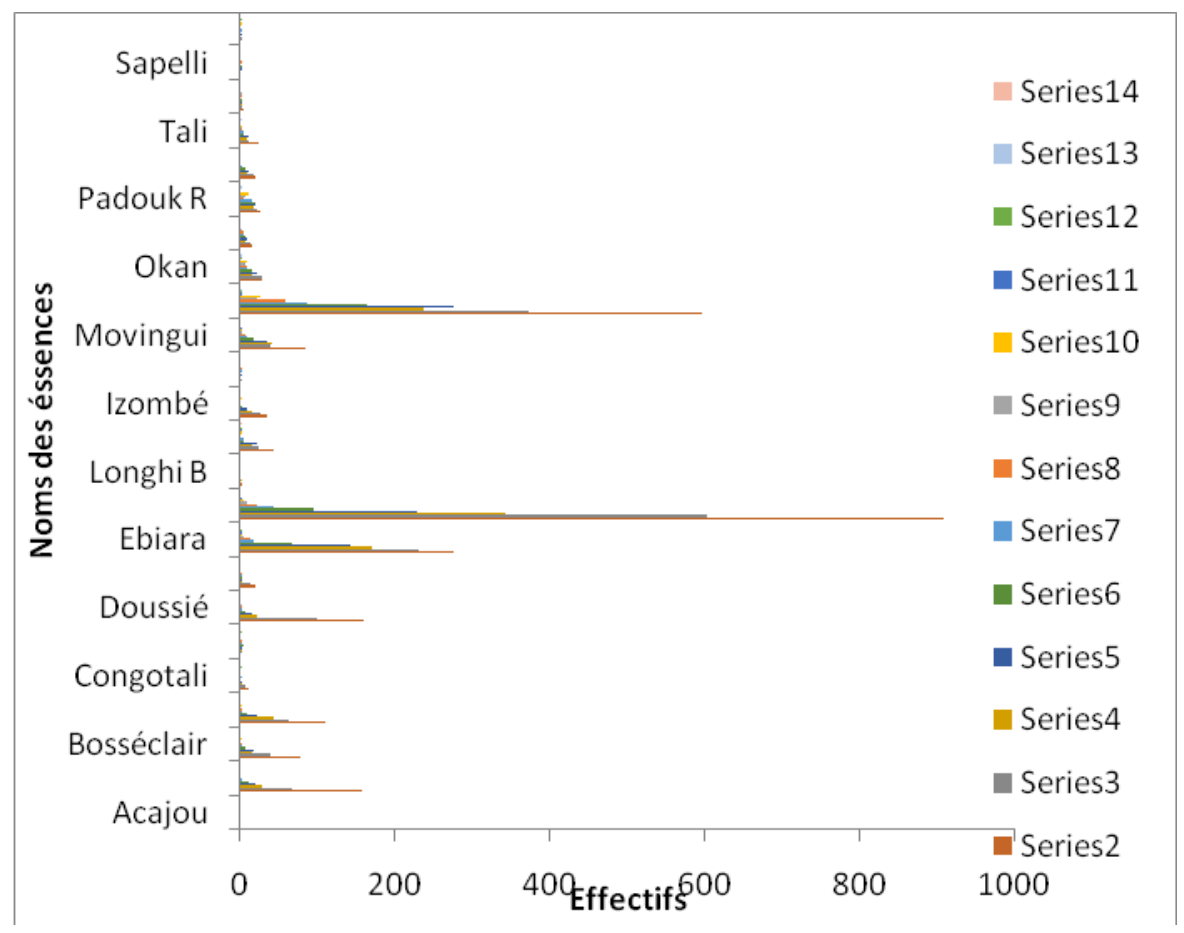

Face.4 Repartition of medium volumes according to essences and diameter classes

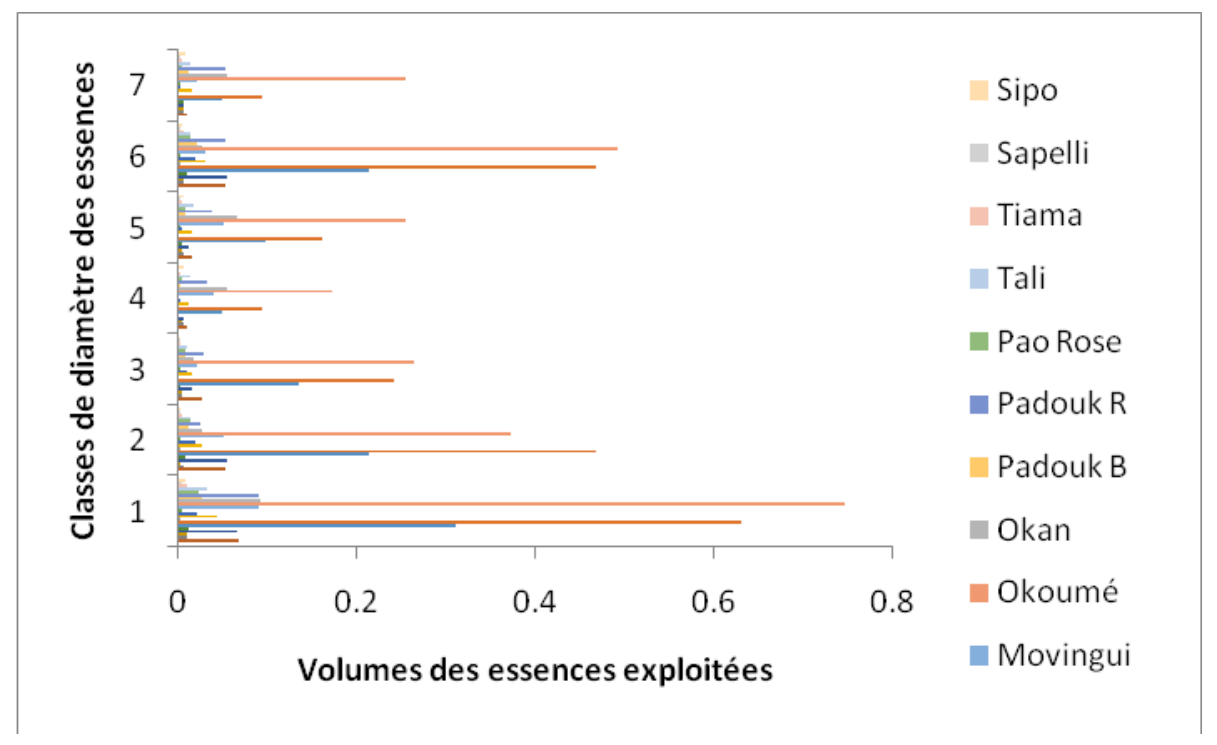


Face.5 Repartition of the terrior area according to diameter classes comprise between 10-14, of the most exploited essences

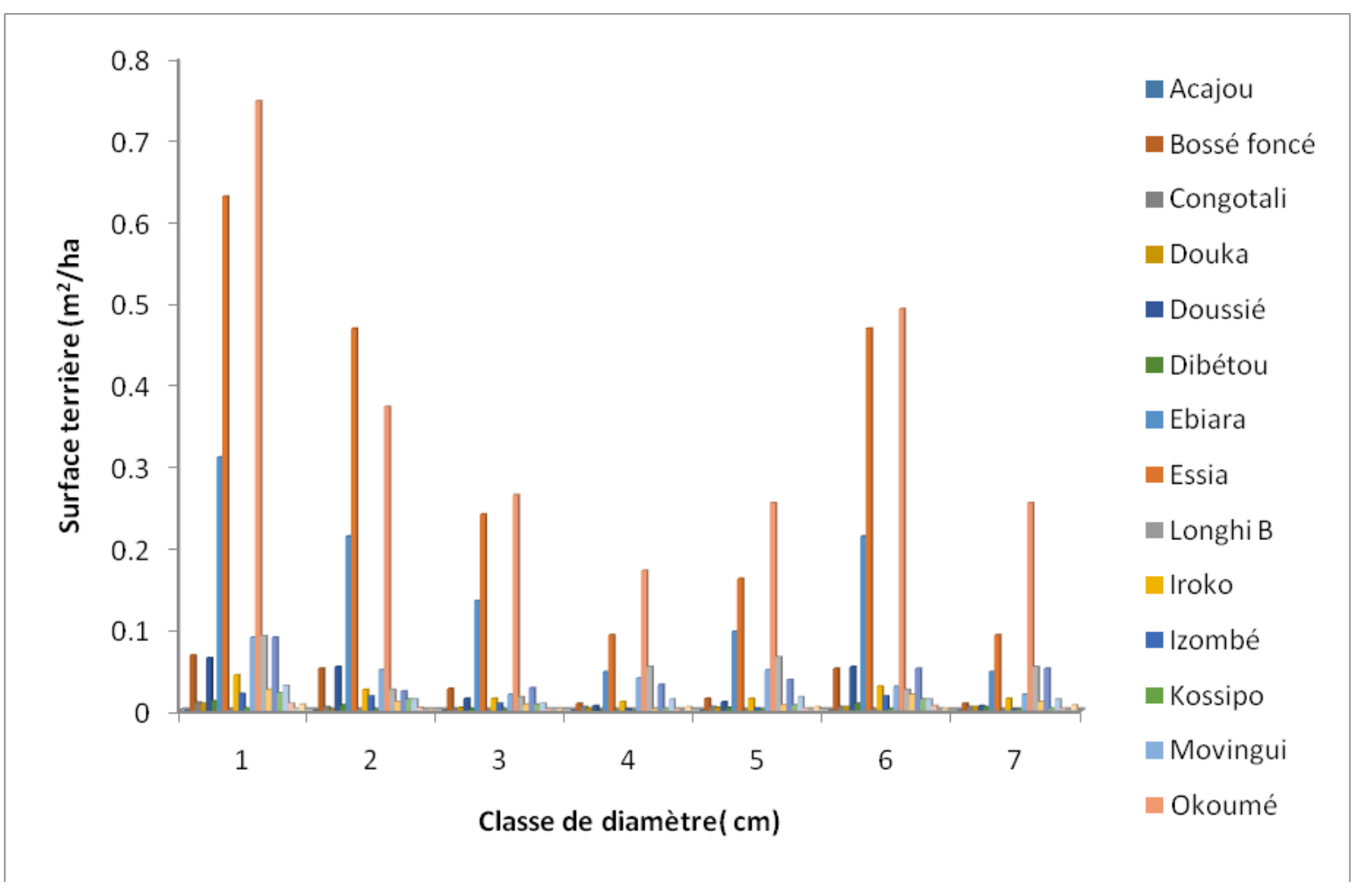

For the exploitable stalks, we have also the presence of asecond group of essences of which the coefficient of variation are for some of them acceptable and other pratically not. It is about the Ebiara with a medium number $(0$, 14 stalks/ha) and a coefficient of variation $331,58 \%$, followed by red Padouk with $(0,08$ stalks/ha) and a coefficient $392,18 \%$, the Okan $(0,07 \mathrm{stalks} / \mathrm{ha}) \quad$ and $\quad \mathrm{a}$ coefficient424,87\%. Movingui with $(0,01$ stalk $/ \mathrm{ha})$ and a coefficient of variation $370,26 \%$, the dark Bossé with $(0,03$ stalks/ha) and a coefficient $789,62 \%$. The essences such as the Doussié (860,71 stalks/ha), light Bossé $(930,57 \%)$ and the Bilinga $(946,74 \%)$ present each of them $(0,02$ stalks/ha).

The coefficients of variation of those last essences having enough high, we think that in those forestery exploitation conditions, they would be source of difficulties notably in terms of debusquing and docting of vegetable material especially as the group is a little bit with bunt.

This exploitation would not perhaps make possible the costs linked to the exploitation. The representation of this second group is $43,02 \%$.

The terrior occupied by our taxons is $2,40 \mathrm{~m}^{2} /$ ha of which $0,79 \mathrm{~m}^{2} /$ ha for stalks of which the diameters are $>$ or $=$ to the maximum diameter of exploitation fixed by the entreprise and to the official maximum diameter of exploitation of the forestery administration and $0,85 \mathrm{~m}^{2} / \mathrm{ha}$ for last classes of diameter immediately inferior to the official maximum diameters of exploitation. Taxons which occupy a considerable terrior erea are: the Okoumé $\left(0,75 \mathrm{~m}^{2} / \mathrm{ha}\right)$ followed by Essia $(0,63 \mathrm{~m} 2 / \mathrm{ha})$ and of the Ebiara $\left(0,31 \mathrm{~m}^{2} / \mathrm{ha}\right)$. 
Concerning the medium volume: we thing that all exploited forestry in Africa bases his accounting only on the volume of woods obtained. In our case, we see that the Okoumé presents a medium volume $\left(1,927 \mathrm{~m}^{3} / \mathrm{ha}\right)$ followed by Essia $\left(1,196 \mathrm{~m}^{3} / \mathrm{ha}\right)$ are predominant essences at the level of inventory block 9. Those two essences to the only them present a great percentage of representativity, given about $48,74 \%$ of set of essences possible for exploitation.

A second group where we meet essences suchas the Ebiara $\left(0,730 \mathrm{~m}^{3} / \mathrm{ha}\right)$, followed by the Okan $\left(0,525 \mathrm{~m}^{3} / \mathrm{ha}\right)$, the red Padouk $\left(0,435 \mathrm{~m}^{3} / \mathrm{ha}\right)$, the Movingui $\left(0,323 \mathrm{~m}^{3} / \mathrm{ha}\right)$, the dark Bossé $\left(0,126 \mathrm{~m}^{3} / \mathrm{ha}\right)$, the Doussié $\left(0,109 \mathrm{~m}^{3} / \mathrm{ha}\right)$ and the Bilinga $\left(0,089 \mathrm{~m}^{3} / \mathrm{ha}\right)$ present medium volumes less considerable.

Those essences have got a representativity 14,79\% (Mbete and others 2018) had obtained the same results in the same Exploitation Forestery Unity (UFE) during the planing inventory of block A, those authers have shown that the relative dominance of densities of exploited stalks by enterprise was the Essia essence (Petersianthus macrocarpus) whichis predominant and represents (5,35 feets/ha), followed by the Okoumé (Aucoumea Klaineana) with $(4,18$ feet/ha) and then Ebiara (Berlinia bracteosa) with $(2,40$ feet/ha). The other essences are less represented, some practically not.

Base on its erea and biolodiversity, the management of forestery Unity of Exploitation is non and ever a highly stragic question aegarding threatens which exist in the ecological and environmental balances (Mbete, 2014).

(Badevokila, 2009) already thinks that Congo occuies a class one in the forestery domain in the Central Africa and is a weighty speaker because of its production in the management of common strategies and politics to be adopted.

Okoumé essence which is more researched in the area (Leroy-Deval, 1988) shows that the essences is also in the borders of the big forest where it is disseminated and badly regenerated. It deseappears as seen as the altitude increases (up to $500 \mathrm{~m}$ ), that is why the planification of the works of estimation of ressources is very important before thinking to exploitation which at least is a destructive operation of forestery ecosystems despite the management and financial measres put in place.

In conclusion, the inventory of large woody trees of the Exploitation Forest Unit (UFE) takes place in the southern zone of Congo Brazzaville more precisely in the UFE Gouongo.

Indeed, the Laboratory of Applied Ecology and the Environment together with the students of the national higher school of agronomy and forestry of the Marien Ngaouabi university in collaboration with the forest administration were involved in the resolution to major works forest inventories of the South zone with a view to sustainably managing the Congolese forests which today had undergone a creaming caused by the approach of the zone vis-à-vis the autonomous port of the Atlantic Ocean, the Congo railway ocean (CFCO) of specific wealth, but also by the presence of carriageways built by the colonial administration.

The results of the analysis of the inventory work only concerned block $\mathrm{B}$, which in turn had a useful area of 3,204.93 ha. We listed a total of twenty-seven (27) exploitable species, but also marketable including: the most abundant species are Essia (2,251 stems), followed by Okoumé (1,837 stems) and 
Ebiara (921 stems). The rest of the stems were poorly represented It is noted that the classes of diameters taken into account were constituted only between the intervals included] 0-5 [cm. The results of the diameter classes showed that, the diameter class 2 whose stems are between] 5-10 [represents the dominant class which undergoes a lot of impacts during the felling and skidding operations of the woods especially for the fragile essences Monitoring of class 3 with stems having a diameter between] 10-15 [then classes 4 and 5 for future rotations of logging.

As for classes 6 and 8 are less represented and the classes or trees have exploitable diameters often accepted by the forestry administration.

From class 12 to class 14 , these trees can be considered as future seeders. We also note that in the area, the species Okoumé (Aucoumea klainneana) and the limba (Terminalia superba) are the essences of light since the gaps in forest operations, very spontaneously increase young stems as well as shoots from felled trees. These young regeneration stems can be considered as the species of the future provided that the developments carried out in the area by the forest administration of the country are carefully observed and applied by the companies that will be responsible for managing these forests.

We also note that in the area, the species Okoumé (Aucoumea klainneana) and the limba (Terminalia superba) are the essences of light since the gaps in forest operations, very spontaneously increase young stems as well as shoots from felled trees. These young regeneration stems can be considered as the species of the future provided that the developments carried out in the area by the forest administration of the country are carefully observed and applied by the companies that will be responsible

\section{References}

Badevokila. 2009. Carbonisation industrielle du charbon de bois pour préserver nos forêts: lutter contre, la pollution et contribuer à un développement propre et durable au service de l'économie locale. Ed. André Donnot. NancyUniversité. 71p.

Cniaf/Pagef., 2012. Rapport dendrométrique $\mathrm{n}^{\circ} 2$ : Etablissement des tarifs de cubage dans la zone Chaillu sur les UFE Gouongo, Massanga, Mpoukou-Ogooué et Nyanga. Brazzaville. 38p.

Doucet, J.L., 2003. - L'alliance délicate de la gestion forestière et de la biodiversité dans les forêts du centre du Gabon. Thèse de doctorat, Faculté Universitaire des Sciences Agronomiques, B-5030 Gembloux, 323p.

Leroy - Deval J., 1988. - Note sur la limite de l'air de l'Okoumé dans le Nord-est du Gabon CTFT, Gabon. Revue Bois et Forêt de tropiques $\mathrm{n}^{\mathrm{o}} 215,1^{\mathrm{er}}$ trimestre 1988, pp 27-35.

FAO., 2011. La situation des forêts dans le bassin amazonien, le bassin du Congo et 1'Asie du Sud-Est 80p.

FAO., 2003. Code Régional d'exploitation forestière à faible impact dans les forêts denses tropicales humides d'Afrique Centrale et de l'Ouest $152 \mathrm{p}$.

Mbete PIERRE., 2014. Evaluation de l'incidence des opérations de l'exploitation forestière sur la végétation et la faune dans l'unité forestière d'aménagement de MokabiDzanga. Thèse de doctorat unique, Université Marien Ngouabi: Faculté des Sciences et Techniques. 217p.

Mbete PIERRE., Moukilou Georges., Binsangou Stoffenne., 2015. Inventorie of the regeneration of gases exploited in the forest yard of SICOFOR: Case of the Forest unit of exploitation (UFE) of Gouongo (South Congo) Revue Journal 
of Multidisciplinary Engineering Science and Technology ISSN: 31590040. Vol. 2 Issue 1, January-2015. pp 30-38.

Mbete PIERRE and Oko Sosthene Clement. 2018. Évaluation de l'abattage contrôlé et estimation des pertesde bois en grume dans l'Unité Forestière d'Aménagement Loundoungou-Toukoulaka au Nord Congo. Journal of Applied Biosciences 123: 12319-12331. ISSN 1997-5902.

Mbete PIERRE and Oko Clement Sosthene. 2018. Estimation of Forest Resources in the Framework of a Forest Management Project of the Forest Exploitation Unit (UFE) of Nyanga. International Journal of Trend in Research and Development, Volume 5(3), ISSN: 2394-9333 www.ijtrd.com. 154-163p.

Moukilou Georges., 2012. Table de programmation de traitement des données des inventaires dendrométriques. Version 12.0. 54p.

OSFAC., 2011. Les forêts du bassin du Congo: Etat des forêts, Yaoundé, 274p.

UICN/PACO., 2012. Evaluation de l'efficacité de gestion des aires protégées. Ouagadougou, BF: UICN/PACO. 135p.

Vennetier., 1977. Atlas jeune Afrique, République populaire du Congo $1^{\text {ère }}$ Edition 64p.

\section{How to cite this article:}

Pierre MBETE. 2020. Processing Use and Analysis of Inventory (stock-taking) of the Essences Exploited in the United Forestry Exploitation of Gouongo in the Republic of Congo. Int.J.Curr.Microbiol.App.Sci. 9(06): 4012-4023. doi: https://doi.org/10.20546/ijcmas.2020.906.470 